\title{
Acute and Persistent Hepatitis E Virus Genotype 3 and 4 Infection: Clinical Features, Pathogenesis, and Treatment
}

\author{
Nassim Kamar ${ }^{1}$ and Sven Pischke ${ }^{2}$ \\ ${ }^{1}$ Department of Nephrology and Organ Transplantation, Université Paul Sabatier, Toulouse 31059, France \\ ${ }^{2}$ Department of Medicine I, University Medical Center Hamburg-Eppendorf, Hamburg 20251, Germany \\ Correspondence: kamar.n@chu-toulouse.fr; s.pischke@uke.de
}

Hepatitis E virus (HEV) genotype (gt) 3 and 4 infections are prevalent in industrialized and high-income countries. Although most HEV gt3 and gt4 infections are clinically silent, acute infection may be symptomatic in some patients. In persons with underlying liver disease and in elderly men, HEV infections may present as acute or acute-on-chronic liver failure. Chronic hepatitis may develop in immunosuppressed individuals, including transplant recipients, human immunodeficiency virus (HIV)-infected patients, and persons with hematologic malignancy undergoing chemotherapy, and may progress to life-threatening liver cirrhosis. Extrahepatic manifestations of infection may include neurological and renal disease. Although there is no approved specific therapy for the treatment of acute or chronic HEV gt 3 or gt 4 infection, off-label use of ribavirin appears to be capable of eliminating chronic $\mathrm{HEV}$ infection, and may reduce disease severity in patients suffering from acute liver failure.

Farly studies suggested that hepatitis $\mathrm{E}$ virus E(HEV) was largely limited to underdeveloped regions of the world, mainly South, Central, and Southeast Asia, Africa, the Middle East, and Mexico, and only rarely caused sporadic, usually imported, infections in industrialized, high-income countries. In the absence of fulminant disease, HEV infection was also considered to be self-limited without the potential for persistence and chronic hepatitis. However, within the last two decades, these assessments have changed. Indeed, infection with genotype (gt) 3 or gt4 HEV is now known to be prevalent in many economically advanced countries, and chronic gt3 HEV infection has been recognized in immunosuppressed patients (Kamar et al. 2008; Dalton et al. 2009).

HEV infections in developing countries are generally caused by gt 1 and gt $2 \mathrm{HEV}$, at times in association with large, waterborne outbreaks of disease. In contrast, gt 3 and gt $4 \mathrm{HEV}$ are prevalent in high-income countries. Zoonotic transmission, predominantly from infected swine via consumption of poorly cooked or raw pork, is generally considered to be the major source of HEV gt3 and gt4 infection (Wedemeyer et al. 2012; see Dalton and Izopet 2018). The prevalence of infection can be estimated from the frequency with which HEV RNA-positivity is found among blood donors (Table 1). A few

Editors: Stanley M. Lemon and Christopher Walker

Additional Perspectives on Enteric Hepatitis Viruses available at www.perspectivesinmedicine.org

Copyright (C) 2019 Cold Spring Harbor Laboratory Press; all rights reserved; doi: 10.1101/cshperspect.a031872

Cite this article as Cold Spring Harb Perspect Med 2019;9:a031872 
N. Kamar and S. Pischke

Table 1. HEV prevalence in blood donors

\begin{tabular}{lllll}
\hline Country & \multicolumn{1}{c}{ Method } & Samples & Results & \multicolumn{1}{c}{ References } \\
\hline Ghana & Individual testing & 239 & $0 / 239$ & Meldal et al. 2013 \\
United States & Individual testing & 1939 & $0 / 1939$ & Xu et al. 2013 \\
Canada & Pools of 48/100 & 13.993 & $0 / 13.993$ & Fearon et al. 2017 \\
Australia & Pools of 6 & 74.131 & $1 / 74.131$ & Hoad et al. 2017 \\
United States & Pools of 96 & 128.020 & $1 / 32.005$ & Roth et al. 2017 \\
United States & Individual testing & 18.829 & $1 / 9500$ & Stramer 2014 \\
Germany & Pools of 96 & 18.100 & $1 / 4525$ & Baylis et al. 2012 \\
Spain & Individual testing & 9.998 & $1 / 3333$ & Sauleda et al. 2014 \\
United Kingdom & Pools of 24 & 225.000 & $1 / 2850$ & Hewitt et al. 2014 \\
France & Pools of 96 & 53.234 & $1 / 2218$ & Gallian et al. 2014 \\
The Netherlands & Pools of 96/192 & 59.474 & $1 / 1440$ & Hogema et al. 2016 \\
Germany & Pools of 48 & 16.000 & $1 / 1250$ & Vollmer et al. 2012 \\
\hline
\end{tabular}

larger studies have identified HEV RNA in up to $0.037 \%$ of blood donations (Hewitt et al. 2014), although other studies have not identified positive donors (Xu et al. 2011; Meldal et al. 2013; Fearon et al. 2017). This could be related to differences in cohort sizes.

HEV infection has specific clinical and epidemiological features that differ depending on the underlying genotype of the infecting virus. For example, high mortality rates have been reported in women with acute HEV gt1 or gt2 infection during pregnancy (Acharya et al. 1996; Bhatia et al. 2008; Aggarwal and Jameel 2011), whereas there is no apparent increased risk of mortality if pregnant women are infected by gt 3 or gt 4 virus.

This review aims to summarize the clinical course, pathogenesis, and treatment options for acute and chronic gt 3 and gt $4 \mathrm{HEV}$ infection in immunocompetent and immunosuppressed individuals.

\section{PATHOGENESIS OF ACUTE AND CHRONIC HEV gt3 AND gt4 INFECTIONS}

Most HEV gt3 and gt4 infections in immunocompetent individuals are self-limited and result only in clinically silent seroconversion. Less than $2 \%$ of those infected are symptomatic (Wedemeyer and Pischke 2011; Rein et al. 2012). The viral and host-related factors that influence the severity of HEV infections have yet to be determined (Fig. 1). Much of what is known of the pathogenesis of these infections comes from studies of nonhuman primates (see Cullen and Lemon 2018; Lanford et al. 2018).

Infection with gt 3 or gt $4 \mathrm{HEV}$ can be considered to involve three distinct temporal phases, including an incubation period, an acute phase, and a recovery phase. Viral replication is evident within the liver by about 7 days after exposure to the virus. The percentage of infected hepatocytes is unknown, but HEV RNA can be detected in the serum a few days before symptoms of hepatitis. Serum alanine aminotransferase (ALT) levels increase with the onset of symptoms, with ALT and serum HEV RNA levels peaking about 4 to 8 weeks after infection. In nonimmunosuppressed patients, viral replication persists for a few weeks in association with fecal virus shedding. HEV RNA continues to be shed in the stool for a few weeks after becoming undetectable in the serum (Aggarwal et al. 2000). The nature of immunity subsequent to clearance of the infection is not well known.

In contrast to such self-limited infections, viral RNA can remain detectable in the serum and stools for prolonged periods in patients with compromised immune systems (Kamar et al. 2008; Legrand-Abravanel et al. 2010). HEV infection can result in chronic hepatitis in such patients, defined by persistence of virus replication and hepatic inflammation for $>3-6$ months Whether acute HEV infection resolves without sequelae or progresses into chronic hepatitis seems to be related primarily to the host's im- 


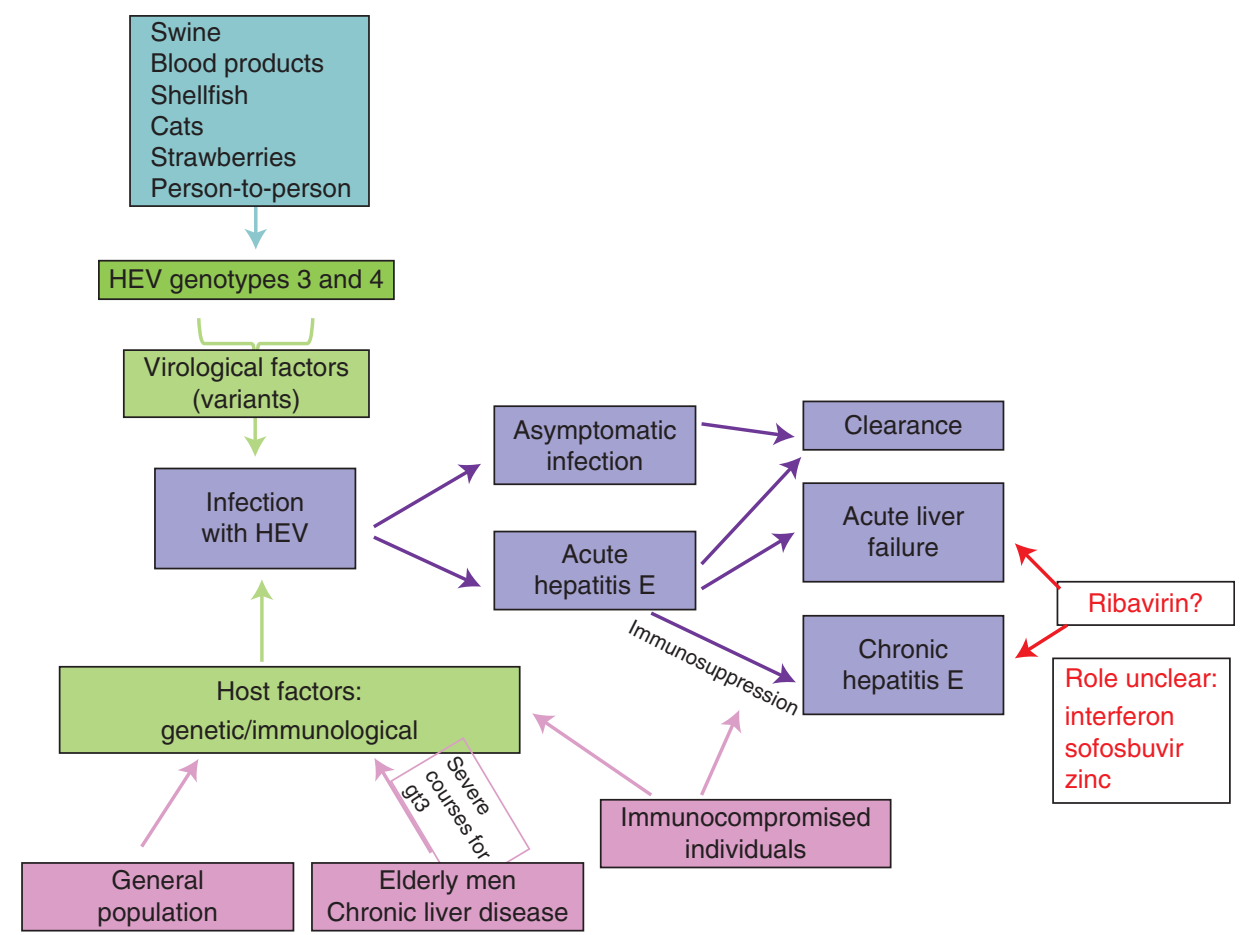

Figure 1. Possible clinical outcomes of genotype (gt)3/4 hepatitis E virus (HEV) infections.

mune response (Fig. 1) (Suneetha et al. 2012; Abravanel et al. 2016). Indeed, chronic HEV infection has been only described in immunosuppressed patients. A decrease in the HEV-specific $\mathrm{T}$-cell response has been reported in transplant recipients who develop chronic versus resolving $\mathrm{HEV}$ infections (Suneetha et al. 2012). Cell culture studies suggest that the virus is noncytopathic, but the mechanism(s) responsible for liver injury in either acutely or persistently infected patients are poorly understood.

Infection with $\mathrm{HEV}$ gt3 and gt 4 can also cause fulminant hepatitis, but pregnant women do not appear to be at increased risk for this, as they are with gt $1 \mathrm{HEV}$. gt $3 \mathrm{HEV}$ has also been associated with extrahepatic manifestations of disease, including both neurological and kidney injury as described below (Kamar et al. 2012a; Pischke et al. 2017). Preliminary evidence for extrahepatic replication of the virus has been obtained in animals and humans based on immunohistochemical detection of HEV antigen and/or detection of negative-strand HEV RNA within the gastrointestinal tract (Williams et al.
2001; Izopet et al. 2012), placenta (Bose et al. 2014), central nervous system (Drave et al. 2016), and kidney (Geng et al. 2016). However, the pathogenic mechanisms responsible for extrahepatic disease remain ill-defined (Fig. 2).

\section{CLINICAL COURSE OF ACUTE HEV INFECTION IN OTHERWISE HEALTHY INDIVIDUALS}

As indicated above, HEV gt3 or gt4 infections vary widely in severity, from clinically silent to fulminant hepatitis (Fig. 1). In immunocompetent patients, HEV infection leads to symptomatic hepatitis in $<2 \%$ of cases (Zhu et al. 2010; Wedemeyer and Pischke 2011). The incubation period in immunocompetent individuals ranges from 21 to 56 days, with a mean of 40 days (Wedemeyer et al. 2012).

There are no symptoms that specifically differentiate acute $\mathrm{HEV}$ infection from other causes of viral hepatitis. Similar to acute hepatitis A, a short prodromal phase with nonspecific symptoms, including a flu-like syndrome of myalgia, 


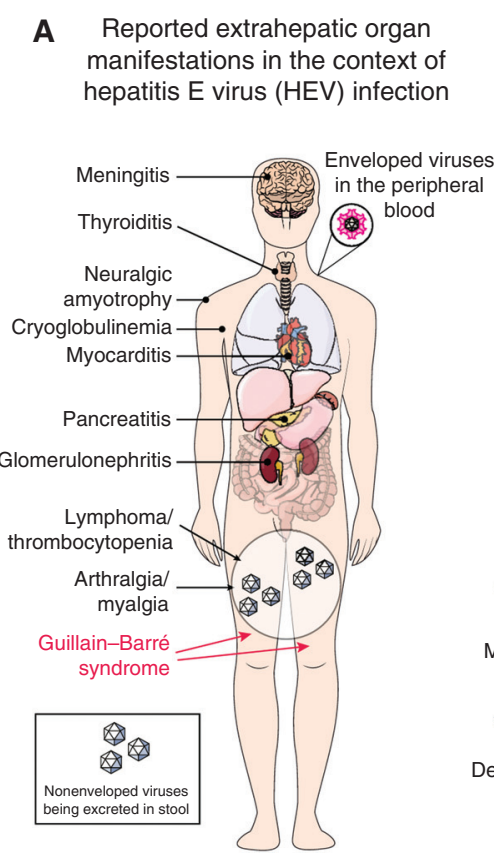

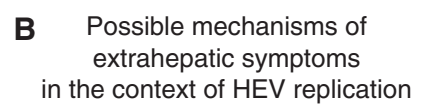

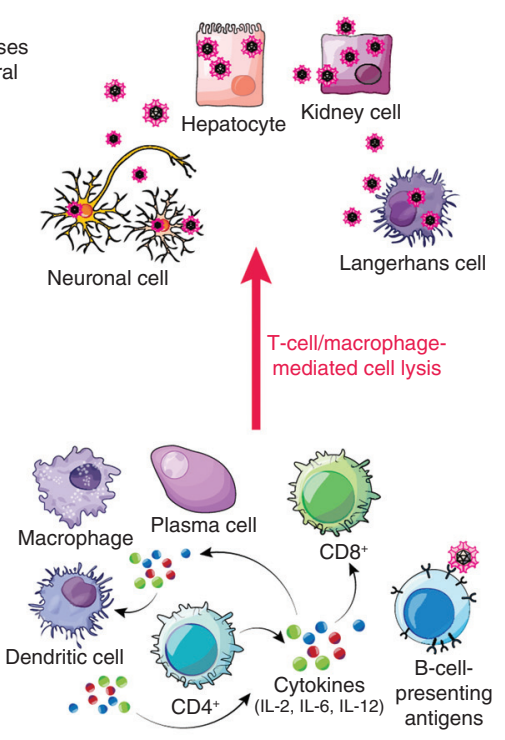

C Possible mechanisms of neurological manifestations in the absence of HEV replication

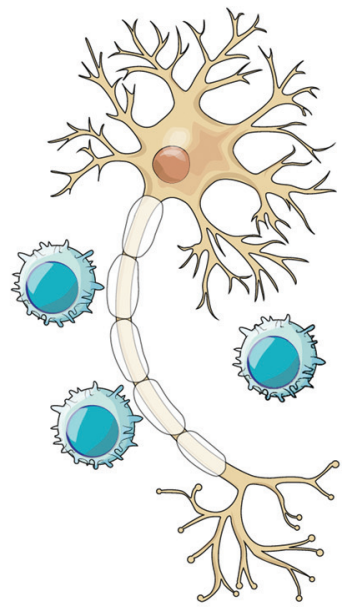

Figure 2. Potential extrahepatic manifestations of genotype (gt)3/4 HEV infection. (A) Extrahepatic disease manifestations reported in the context of acute HEV infection. Underlying mechanisms of pathogenesis are unclear but could involve either $(B)$ virus replication in tissues other than the liver, or $(C)$ collateral damage from immune responses to HEV infection in the liver including, for example, immune complex formation or molecular mimicry resulting in nerve injury. (From Pischke et al. 2017; adapted, with permission, from Elsevier (c) 2017.)

arthralgia, asthenia, nausea, and vomiting, is followed by more "liver-specific" symptoms and signs, such as jaundice, pruritus, clay-colored stools, and darkened urine. Serum ALT levels usually peak about 6 weeks after exposure (Wedemeyer et al. 2012). ALT elevations are usually higher than increases of aspartate aminotransferase (AST), and frequently accompanied by an increase in alkaline phosphatase, $\gamma$-glutamyl-transpeptidase (GGTP), and bilirubin. In contrast to HEV gt 1 or gt 2 , HEV gt 3 or gt 4 do not appear to cause fatal infections with fulminant hepatitis in pregnant women (Lachish et al. 2015).

\section{ACUTE HEV INFECTION IN THE ELDERLY AND IN THOSE WITH UNDERLYING CHRONIC LIVER DISEASE}

In elderly patients and/or those with underlying liver disease, acute HEV infection may present as acute-on-chronic hepatitis, leading to decompensated cirrhosis, fulminant hepatitis, and death. A recent Swiss study described 93 cases of primarily asymptomatic autochthonous HEV gt 3 and gt 4 infection, and found that male gender and older age were risk factors for symptomatic disease (Fraga et al. 2017). In another recent study investigating clinical characteristics and outcomes of acute sporadic HEV infection in China, underlying chronic liver disease was identified as a risk factor for a worse outcome and increased mortality (Zhang et al. 2017). The clinical course is similar to acute exacerbations of chronic hepatitis because of other causes (Blasco-Perrin et al. 2015). The risk of death may be as high as $70 \%$ in cases in which HEV infection is associated with severe acute-on-chronic hepatitis (Peron et al. 2007; Kumar and Saraswat 2013).

In a study centered in the United Kingdom and France, acute HEV infection was identified 
in $3.2 \%$ of 343 patients with acute decompensated hepatitis (Blasco-Perrin et al. 2015). In contrast, no evidence of HEV infection was found in a cohort of 40 patients from Gambia with acuteon-chronic liver failure (Shimakawa et al. 2016). Acute hepatitis caused by HEV infection may be misdiagnosed as acute drug-induced liver injury or as autoimmune hepatitis. A study from the United States investigated 681 patients with acute liver failure caused by various factors and found $\mathrm{HEV}$ infection to be the cause in only $0.4 \%$ of cases (Fontana et al. 2016). In a British study of 47 suspected cases of drug-induced liver injury, $13 \%$ were actually caused by $\mathrm{HEV}$ infection (Dalton et al.2007). Although it may be relatively uncommon, HEV infection should be considered in patients presenting with suspected drug-induced liver injury or an otherwise unexplained acute exacerbation of chronic hepatitis.

\section{CHRONIC HEV INFECTION IN TRANSPLANT RECIPIENTS}

Similar to otherwise healthy individuals, an incubation period of 50-60 days was observed before the onset of liver disease in several transplant recipients and immunosuppressed patients transfused with HEV-contaminated blood products (Pischke et al. 2016). Such patients are at risk for chronic $\mathrm{HEV}$ infection, which has been defined generally as the persistence of HEV RNA in serum and/or stool for periods longer than 3 to 6 months (Kamar et al. 2013). Chronic HEV infection was first reported in cohorts of European transplant recipients beginning in 2008 (Gerolami et al. 2008; Kamar et al. 2008; Haagsma et al. 2009; Pischke et al. 2010). Initially, 14 cases of acute HEV infection were reported among kidney- and liver-transplant recipients (Kamar et al. 2008). Eight of these patients developed persistent HEV infections with chronically elevated ALT and portal inflammatory infiltrates with mild piecemeal necrosis, progressing to histologically proven fibrosis within 12 months of infection.

How commonly acute HEV infection persists in transplant recipients is still debated, however. A multicenter retrospective European study showed that $66 \%$ of transplant recipients with an overt acute HEV infection developed chronic hepatitis E (Kamar et al. 2011b). Because of the retrospective design of this study, however, some asymptomatic HEV infections may have been missed. Other studies that have focused on seroconversion rates among transplant recipients and have thus included both symptomatic and asymptomatic cases of $\mathrm{HEV}$ infection, have reported rates of progression to chronicity ranging from $21 \%$ to $50 \%$ (LegrandAbravanel et al. 2011; Pischke et al. 2012, 2013).

The risk of chronic HEV infection in transplant recipients may depend on the specific immunosuppressive regimen, as well as the intensity of immunosuppression (Suneetha et al. 2012). The use of tacrolimus, rather than cyclosporine $\mathrm{A}$, has been associated with an increased risk of chronic hepatitis (Kamar et al. 2011b), whereas the use of mycophenolic acid was associated with a lower likelihood of chronic hepatitis (Pischke et al. 2012). Interestingly, in vitro studies suggest that calcineurin inhibitors may stimulate HEV replication, whereas mycophenolic acid may inhibit it (Wang et al. 2014). A very low prevalence of chronic $\mathrm{HEV}$ infection was reported in a large cohort of Japanese liver transplant recipients, suggesting that there may be HEV subtype- or strain-specific differences, or host genetic factors that influence the likelihood of viral persistence (Inagaki et al. 2015; Pischke and Wedemeyer 2015). Despite the potential for persistent infection and chronic hepatitis, fulminant liver failure has not been reported in $\mathrm{HEV}$-infected transplant recipients.

Nearly all cases of chronic HEV infection have been reported in patients infected with HEV gt3; only a few cases of HEV gt 4 chronic infection have been reported (Geng et al. 2014, 2016). Recently, however, persistent HEV gt7 and gt8 infections (derived from camels) have been recognized in transplant recipients (Lee et al. 2016). No case of chronic HEV infection caused by gt 1 or gt 2 has been reported.

\section{CHRONIC HEV INFECTIONS BEYOND SOLID-ORGAN TRANSPLANT RECIPIENTS}

Chronic HEV infections have been described in patients infected with human immunodeficien- 
N. Kamar and S. Pischke

cy virus (HIV) infection (Dalton et al. 2009, 2013), mainly in those with impaired immune responses. In contrast to transplant recipients, however, several studies of HIV-infected patients report very low rates of chronic HEV infection, ranging from 0 to $0.003 \%$. HEV infection may persist in HIV-infected patients despite improvements in immune status (Ingiliz et al. 2016). Chronic HEV infections have also been reported in patients with hematological malignancies receiving chemotherapy (Tamura et al. 2007; Geng et al. 2014), stem-cell transplant recipients (Versluis et al. 2013), and in others with underlying immunosuppression, including patients with systemic lupus erythematosus (SLE), granulomatosis, retroperitoneal fibrosis, or CD4 T-cell deficiency (Honer zu Siederdissen et al. 2014).

\section{EXTRAEXTRS HEPATIC MANIFESTATIONS OF HEV gt3 AND gt4 INFECTIONS}

Although a number of extrahepatic manifestations have been reported in association with HEV infection over the past decade, causal pathophysiologic links with HEV remain poorly defined (Fig. 2). The best evidence for a causal association exists for the Guillain-Barré syndrome, neuralgic amyotrophy, glomerulonephritis, and cryoglobulinemia (Fig. 2) (Kamar et al. 2016). Pancreatitis, which has been observed in patients infected with gt1 and gt2 $\mathrm{HEV}$, does not appear to be associated with gt3 or gt4 HEV infections (Kamar et al. 2012b).

\section{Neurological Manifestations}

Neurological findings have been reported frequently in association with acute or chronic HEV infection (Comont et al. 2013). These involve primarily the peripheral nervous system, and include neuralgic amyotrophy (NA), Guillain-Barré syndrome, Bell's palsy (seventh cranial nerve), and polyradiculopathy (Dalton et al. 2017). In a large study of $126 \mathrm{HEV}$-infected patients from France and Great Britain, more than $5 \%$ developed neurologic complications in the context of acute gt3 infection (Kamar et al. 2011a). In some cases, HEV RNA has been de- tected in the cerebrospinal fluid (Comont et al 2013).

A particularly strong association exists between gt3 HEV infection and NA, also known as Parsonage-Turner syndrome or brachial neuritis. This rare, postinfectious disorder of the brachial plexus presents clinically with the acute onset of severe shoulder and arm pain, followed by weakness and atrophy. A recent study of NA patients in Cornwall (United Kingdom) and the Netherlands showed that five of 47 (11\%) had acute HEV gt3 infection (van Eijk et al. 2014). Another recent multicenter European study compared NA in subjects with (57 cases) or without (61 cases) evidence of HEV infection (van Eijk et al. 2017). Patients with HEV-associated NA had predominantly bilateral asymmetrical involvement of the brachial plexus (van Eijk et al. 2017). They were mostly anicteric.

Three case-control studies have confirmed a relationship between HEV infection and Guillain-Barré syndrome. HEV infection was diagnosed at the start of the neurological illness in $5 \%-11 \%$ of patients, which was a significantly more than in healthy controls (Geurtsvankessel et al. 2013; van den Berg et al. 2014; Fukae et al. 2016). In a recent cohort study, six of $73(8 \%)$ patients with Guillain-Barré syndrome had evidence of HEV infection (Stevens et al. 2017).

The association between HEV and other neurological disorders is still under debate. In a recent large study of 464 patients who presented at emergency rooms with nontraumatic neurological symptoms, sera were tested for antiHEV immunoglobulin (Ig)M and HEV RNA by reverse transcription polymerase chain reaction (RT-PCR) (Dalton et al. 2017). Seven patients tested positive for HEV RNA, and four additional patients that tested negative by RTPCR had detectable anti-HEV IgM as a marker of acute HEV exposure. None of these patients were jaundiced. Those with evidence of HEV infection presented with various neurological findings, including NA $(n=3)$, cerebral ischemia or infarction $(n=4)$, seizure $(n=2)$, encephalitis $(n=1)$, and acute combined facial and vestibular neuropathy $(n=1)$ (Dalton et al. 2017). 
In summary, it seems clear that HEV infection may be causally related to the development of some peripheral neurological diseases. The underlying mechanism(s), however, are unknown and open to speculation (Fig. 2C).

\section{Renal Injury}

There is growing evidence for an association of HEV infection with renal disease. In a cohort of 51 kidney and liver transplant recipients, the glomerular filtration rate was significantly decreased during acute and chronic phases of HEV infection (Kamar et al. 2012b). In addition, kidney biopsies from immunocompetent patients, as well as solid-organ transplant recipients, with either acute or chronic HEV infection have revealed membranoproliferative or membranous glomerulonephritis with or without cryoglobulinemia (Kamar et al. 2012b; Taton et al. 2013; Del Bello et al. 2015; Guinault et al. 2016). Relapses have also been reported in HEV-infected patients with IgA nephropathy (Kamar et al. 2012b). Mechanisms responsible for renal damage have not been studied in detail, but HEV RNA and HEV antigens have been detected in the urine of patients as well as in the urine of monkeys and rabbits infected with HEV (Geng et al. 2016; Wang et al. 2016a).

\section{THERAPEUTIC APPROACHES FOR HEV INFECTION}

\section{Treatment of Acute HEV Infection}

There is no approved pharmacological intervention for $\mathrm{HEV}$ infection. In most cases of acute $\mathrm{HEV}$ infection, no treatment is required as the disease usually takes a self-limiting and moderate course. In single case reports involving immunocompetent patients with serious liver disease, ribavirin has been suggested to ameliorate HEV-associated acute or acute-onchronic liver failure (Gerolami et al. 2011; Peron et al. 2011; Goyal et al. 2012). Unfortunately, no large double-blind, placebo-controlled study has evaluated the efficacy of ribavirin in this setting.

\section{Treatment of Chronic HEV gt3 and gt4 Infections}

Treatment of chronic HEV infection has been studied mainly in transplant recipients receiving immunosuppressive therapies. Because the strength of the host immune response seems to determine the risk for persistence and disease progression, reducing immunosuppression, especially limiting drugs that target T cells, is considered to be the first-line therapeutic option (Kamar et al. 2010b, 2011b). This approach is supported by the fact that tacrolimus trough levels were significantly lower in patients who cleared a chronic HEV infection compared to those who remained viremic (Kamar et al. 2010 b). A reduction in immunosuppression allowed HEV clearance in up to one-third of patients who were chronically infected (Kamar et al. 2010b, 2011b). Antiviral therapy should be considered in the remaining patients.

Treatment with pegylated interferon $\alpha$ for 3 or 12 months has resulted in a sustained virological response (SVR) in liver transplant recipients with persistent HEV infection (Haagsma et al. 2010; Kamar et al. 2010a). In addition, a number of studies suggest that ribavirin may be effective therapy for chronic HEV infection in solid-organ transplant recipients (Kamar et al. 2010c, 2014; Mallet et al. 2010; Pischke et al. 2013; Riezebos-Brilman et al. 2013). In a few patients with hematological malignancies receiving chemotherapy and in HIV-infected patients, treatment with pegylated interferon alone, ribavirin alone, or a combination of both has been successful (Alric et al. 2010, 2011; Dalton et al. 2011; Hajji et al. 2013; Neukam et al. 2013; Tavitian et al. 2015).

In a retrospective multicenter study of 59 transplant recipients, ribavirin treatment resulted in an SVR of 78\% (Kamar et al. 2014). The median duration of ribavirin therapy was 3 (range 1-18) months. Patients who relapsed were retreated for longer periods (6 months) with an increase in the overall SVR to $90 \%$ (Kamar et al. 2014). No difference in SVR was observed between patients who received ribavirin for 3 months or less initially versus those who received it for more than 3 months (Kamar et al. 
2014). However, the optimal duration of ribavirin therapy remains unclear, and rigorously controlled clinical trial data remain lacking.

The mechanism of action of ribavirin against $\mathrm{HEV}$ is not fully understood. It has been suggested that ribavirin inhibits HEV replication by depleting cellular pools of guanosine triphosphate (Debing et al. 2014a). Ribavirin is an inhibitor of cellular inosine monophosphate dehydrogenase (IMPDH); mycophenolic acid is also an IMPDH inhibitor and it has been suggested to both prevent HEV persistence in vivo (Pischke et al. 2012) and inhibit HEV replication in vitro (Debing et al. 2014a), especially when combined with ribavirin. In another study of transplant recipients, however, mycophenolic acid did not alter the response to ribavirin therapy (Kamar et al. 2015).

Ribavirin has also been suggested to exert its broad antiviral effects by acting as an RNA mutagen, leading to disruption of viral replication by error catastrophe (Crotty et al. 2001). Consistent with this, studies in treated patients indicate ribavirin induces mutagenesis of the HEV genome (Todt et al. 2016). Next-generation sequencing identified several mutations in the HEV RNA, including a G1634R substitution in the polymerase coding region that appeared to enhance the replicative capacity of the virus in cell culture and may have provided some level of resistance to ribavirin (Debing et al. 2014b, 2016). Ribavirin treatment promoted emergence of the G1634R variant along with a reversible increase in genetic heterogeneity of the virus (Debing et al. 2014b, 2016; Lhomme et al. 2014; Todt et al. 2016). The role of specific HEV variants and their impact on HEV treatment outcomes is uncertain (Lhomme et al. 2012; Debing et al. 2016). Whereas emergence of the G1634 mutation has been associated with treatment failure (Debing et al. 2014b; Todt et al. 2016), its presence does not confer absolute resistance (Lhomme et al. 2015).

An increased lymphocyte count at the initiation of therapy was a positive predictive factor for SVR in patients treated by ribavirin (Kamar et al. 2014), as was a rapid decrease in the serum viral load in association with treatment (Kamar et al. 2010b, 2015). Persistent HEV shedding at the end of therapy was associated with an increased risk of relapse after cessation of ribavirin therapy (Abravanel et al. 2015).

Preliminary in vitro data show that the nucleoside analog sofosbuvir inhibits gt3 HEV replication, and that its antiviral effects are additive with those of ribavirin (Dao Thi et al. 2016). However, its antiviral activity against HEV is modest compared to its effect of hepatitis $\mathrm{C}$ virus, making it of questionable usefulness clinically (Wang et al. 2016b). Combined therapy with sofosbuvir and ribavirin showed promise in treating a patient who did not clear infection with ribavirin (van der Valk et al. 2017), but the role of sofosbuvir in treating HEV infection remains unclear (Kamar et al. 2017).

In vitro studies with HEV RNA replicons show that zinc salts block HEV replication by inhibiting the activity of the viral RNA-dependent RNA polymerase (Kaushik et al. 2017). This observation is of interest as patients with HEV infection may have zinc deficiency (Kolachi et al. 2011), suggesting a possible novel avenue for antiviral intervention.

\section{CONCLUDING REMARKS}

Our understanding of the epidemiology, clinical course, and treatment of HEV gt 3 and gt 4 infections has improved over the last decade. In most cases, infection is asymptomatic. Nevertheless, in specific populations, such as patients who are immunosuppressed, have underlying chronic liver disease, or who are elderly, an HEV infection can cause severe and/or chronic hepatitis. Infection can also be associated with extrahepatic manifestations involving the peripheral nervous system and kidney. A number of studies suggest ribavirin may be effective antiviral therapy in patients with persistent infection. Because of the high prevalence of HEV gt3 (and gt4) in well-developed, industrialized countries, the diagnosis of HEV infection should be considered as a part of a standard work-up for patients presenting with unexplained increases of serum liver enzyme levels. Patients presenting with Parsonage-Turner or Guillain-Barré syndrome should also be screened for HEV, even if liver enzyme levels are within the normal range. 


\section{REFERENCES}

${ }^{*}$ Reference is also in this collection.

Abravanel F, Lhomme S, Rostaing L, Kamar N, Izopet J. 2015. Protracted fecal shedding of HEV during ribavirin therapy predicts treatment relapse. Clin Infect Dis 60: 9699.

Abravanel F, Barrague H, Dorr G, Saune K, Peron JM, Alric L, Kamar N, Izopet J, Champagne E. 2016. Conventional and innate lymphocytes response at the acute phase of HEV infection in transplanted patients. J Infect 72: 723730 .

Acharya SK, Dasarathy S, Kumer TL, Sushma S, Prasanna KS, Tandon A, Sreenivas V, Nijhawan S, Panda SK, Nanda SK, et al. 1996. Fulminant hepatitis in a tropical population: Clinical course, cause, and early predictors of outcome. Hepatology 23: 1448-1455.

Aggarwal R, Jameel S. 2011. Hepatitis E. Hepatology 54: 2218-2226.

Aggarwal R, Kini D, Sofat S, Naik SR, Krawczynski K. 2000. Duration of viraemia and faecal viral excretion in acute hepatitis E. Lancet 356: 1081-1082.

Alric L, Bonnet D, Laurent G, Kamar N, Izopet J. 2010 Chronic hepatitis E virus infection: Successful virologic response to pegylated interferon- $\alpha$ therapy. Ann Intern Med 153: 135-136.

Alric L, Bonnet D, Beynes-Rauzy O, Izopet J, Kamar N. 2011 Definitive clearance of a chronic hepatitis E virus infection with ribavirin treatment. Am J Gastroenterol 106: 1562-1563.

Baylis SA, Gartner T, Nick S, Ovemyr J, Blumel J. 2012. Occurrence of hepatitis E virus RNA in plasma donations from Sweden, Germany and the United States. Vox Sang 103: 89-90.

Bhatia V, Singhal A, Panda SK, Acharya SK. 2008. A 20-year single-center experience with acute liver failure during pregnancy: Is the prognosis really worse? Hepatology 48: $1577-1585$.

Blasco-Perrin H, Madden RG, Stanley A, Crossan C, Hunter JG, Vine L, Lane K, Devooght-Johnson N, McLaughlin C, Petrik J, et al. 2015. Hepatitis E virus in patients with decompensated chronic liver disease: A prospective UK/ French study. Aliment Pharmacol Ther 42: 574-581.

Bose PD, Das BC, Hazam RK, Kumar A, Medhi S, Kar P. 2014. Evidence of extrahepatic replication of hepatitis $\mathrm{E}$ virus in human placenta. J Gen Virol 95: 1266-1271.

Comont T, Bonnet D, Sigur N, Gerdelat A, Legrand-Abravanel F, Kamar N, Alric L. 2013. Acute hepatitis E infection associated with Guillain-Barré syndrome in an immunocompetent patient. Rev Med Interne 35: 333-336.

Crotty S, Cameron CE, Andino R. 2001. RNA virus error catastrophe: Direct molecular test by using ribavirin. Proc Natl Acad Sci 98: 6895-6900.

* Cullen JM, Lemon SM. 2018. Comparative pathology of hepatitis A virus and hepatitis E virus infection. Cold Spring Harb Perspect Med doi: 10.1101/cshperspect.a033456.

* Dalton HR, Izopet J. 2018. The transmission and epidemiology of hepatitis E virus genotype 3 and 4 infections. Cold Spring Harb Perspect Med doi: 10.1101/cshperspect. a032144.
Dalton HR, Fellows HJ, Stableforth W, Joseph M, Thurairajah $\mathrm{PH}$, Warshow $\mathrm{U}$, Hazeldine $\mathrm{S}$, Remnarace $\mathrm{R}, \mathrm{Ijaz} \mathrm{S}$, Hussaini SH, et al. 2007. The role of hepatitis E virus testing in drug-induced liver injury. Aliment Pharmacol Ther 26: 1429-1435.

Dalton HR, Bendall RP, Keane FE, Tedder RS, Ijaz S. 2009. Persistent carriage of hepatitis E virus in patients with HIV infection. N Engl J Med 361: 1025-1027.

Dalton HR, Keane FE, Bendall R, Mathew J, Ijaz S. 2011. Treatment of chronic hepatitis $\mathrm{E}$ in a patient with HIV infection. Ann Intern Med 155: 479-480.

Dalton HR, Hunter JG, Bendall R. 2013. Autochthonous hepatitis $\mathrm{E}$ in developed countries and HEV/HIV coinfection. Semin Liver Dis 33: 50-61.

Dalton HR, van Eijk JJJ, Cintas P, Madden RG, Jones C, Webb GW, Norton B, Pique J, Lutgens S, Devooght-Johnson $\mathrm{N}$, et al. 2017. Hepatitis $\mathrm{E}$ virus infection and acute non-traumatic neurological injury: A prospective multicentre study. J Hepatol 67: 925-932.

Dao Thi VL, Debing Y, Wu X, Rice CM, Neyts J, Moradpour D, Gouttenoire J. 2016. Sofosbuvir inhibits hepatitis E virus replication in vitro and results in an additive effect when combined with ribavirin. Gastroenterology 150: 8285.e84.

Debing Y, Emerson SU, Wang Y, Pan Q, Balzarini J, Dallmeier K, Neyts J. 2014a. Ribavirin inhibits in vitro hepatitis $\mathrm{E}$ virus replication through depletion of cellular GTP pools and is moderately synergistic with $\alpha$ interferon. Antimicrob Agents Chemother 58: 267-273.

Debing Y, Gisa A, Dallmeier K, Pischke S, Bremer B, Manns M, Wedemeyer H, Suneetha PV, Neyts J. 2014b. A mutation in the hepatitis E virus RNA polymerase promotes its replication and associates with ribavirin treatment failure in organ transplant recipients. Gastroenterology 147: 1008-1011.e7; quiz e15-6.

Debing Y, Moradpour D, Neyts J, Gouttenoire J. 2016. Update on hepatitis E virology: Implications for clinical practice. J Hepatol 65: 200-212.

Del Bello A, Guilbeau-Frugier C, Josse AG, Rostaing L, Izopet J, Kamar N. 2015. Successful treatment of hepatitis E virus-associated cryoglobulinemic membranoproliferative glomerulonephritis with ribavirin. Transpl Infect Dis 17: 279-283.

Drave SA, Debing Y, Walter S, Todt D, Engelmann M, Friesland M, Wedemeyer H, Neyts J, Behrendt P, Steinmann E. 2016. Extra-hepatic replication and infection of hepatitis E virus in neuronal-derived cells. J Viral Hepat 23: 512521.

Fearon MA, O'Brien SF, Delage G, Scalia V, Bernier F, Bigham M, Weger S, Prabhu S, Andonov A. 2017. Hepatitis E in Canadian blood donors. Transfusion 57: 1420-1425.

Fontana RJ, Engle RE, Scaglione S, Araya V, Shaikh O, Tillman H, Attar N, Purcell RH, Lee WM, Group USALFS. 2016. The role of hepatitis $\mathrm{E}$ virus infection in adult Americans with acute liver failure. Hepatology 64: 1870-1880.

Fraga M, Doerig C, Moulin H, Bihl F, Brunner F, Mullhaupt B, Ripellino P, Semela D, Stickel F, Beretta-Piccoli BT, et al. 2017. Hepatitis E virus as a cause of acute hepatitis acquired in Switzerland. Liver Int doi: 10.1111/liv.12667.

Fukae J, Tsugawa J, Ouma S, Umezu T, Kusunoki S, Tsuboi Y. 2016. Guillain-Barré and Miller Fisher syndromes in 
N. Kamar and S. Pischke

patients with anti-hepatitis E virus antibody: A hospitalbased survey in Japan. Neurol Sci 37: 1849-1851.

Gallian P, Lhomme S, Piquet Y, Saune K, Abravanel F, Assal A, Tiberghien P, Izopet J. 2014. Hepatitis E virus infections in blood donors, France. Emerg Infect Dis 20: 1914 1917.

Geng Y, Zhang H, Huang W, T JH, Geng K, Li Z, Wang Y. 2014. Persistent hepatitis $E$ virus genotype 4 infection in a child with acute lymphoblastic leukemia. Hepat Mon 14: e15618.

Geng Y, Zhao C, Huang W, Harrison TJ, Zhang H, Geng K, Wang Y. 2016. Detection and assessment of infectivity of hepatitis E virus in urine. J Hepatol 64: 37-43.

Gerolami R, Moal V, Colson P. 2008. Chronic hepatitis E with cirrhosis in a kidney-transplant recipient. $N$ Engl J Med 358: 859-860.

Gerolami R, Borentain P, Raissouni F, Motte A, Solas C, Colson P. 2011. Treatment of severe acute hepatitis E by ribavirin. J Clin Virol 52: 60-62.

Geurtsvankessel CH, Islam Z, Mohammad QD, Jacobs BC, Endtz HP, Osterhaus AD. 2013. Hepatitis E and GuillainBarré syndrome. Clin Infect Dis 57: 1369-1370.

Goyal R, Kumar A, Panda SK, Paul SB, Acharya SK. 2012. Ribavirin therapy for hepatitis $\mathrm{E}$ virus-induced acute on chronic liver failure: A preliminary report. Antivir Ther 17: 1091-1096.

Guinault D, Ribes D, Delas A, Milongo D, Abravanel F, Puissant-Lubrano B, Izopet J, Kamar N. 2016. Hepatitis $\mathrm{E}$ virus-induced cryoglobulinemic glomerulonephritis in a nonimmunocompromised person. Am J Kidney Dis 67: 660-663.

Haagsma EB, Niesters HG, van den Berg AP, Riezebos-Brilman A, Porte RJ, Vennema H, Reimerink JH, Koopmans MP. 2009. Prevalence of hepatitis E virus infection in liver transplant recipients. Liver Transpl 15: 1225-1228.

Haagsma EB, Riezebos-Brilman A, van den Berg AP, Porte RJ, Niesters HG. 2010. Treatment of chronic hepatitis $E$ in liver transplant recipients with pegylated interferon $\alpha-2 b$. Liver Transpl 16: 474-477.

Hajji H, Gerolami R, Solas C, Moreau J, Colson P. 2013. Chronic hepatitis $\mathrm{E}$ resolution in a human immunodeficiency virus (HIV)-infected patient treated with ribavirin. Int J Antimicrob Agents 41: 595-597.

Hewitt PE, Ijaz S, Brailsford SR, Brett R, Dicks S, Haywood B, Kennedy IT, Kitchen A, Patel P, Poh J, et al. 2014. Hepatitis $\mathrm{E}$ virus in blood components: A prevalence and transmission study in southeast England. Lancet 384: 1766-1773.

Hoad VC, Seed CR, Fryk JJ, Harley R, Flower RLP, Hogema BM, Kiely P, Faddy HM. 2017. Hepatitis E virus RNA in Australian blood donors: Prevalence and risk assessment. Vox Sang 112: 614-621.

Hogema BM, Molier M, Sjerps M, de Waal M, van Swieten P, van de Laar T, Molenaar-de Backer M, Zaaijer HL. 2016. Incidence and duration of hepatitis $\mathrm{E}$ virus infection in Dutch blood donors. Transfusion 56: 722-728.

Honer zu Siederdissen C, Pischke S, Schlue J, Deterding K, Hellms T, Schuler-Luttmann S, Schwarz A, Manns MP, Cornberg M, Wedemeyer H. 2014. Chronic hepatitis E virus infection beyond transplantation or human immunodeficiency virus infection. Hepatology 60: 1112-1113.
Inagaki Y, Oshiro $\mathrm{Y}$, Tanaka T, Yoshizumi T, Okajima $\mathrm{H}$, Ishiyama K, Nakanishi C, Hidaka M, Wada H, Hibi T, et al. 2015. A nationwide survey of hepatitis $E$ virus infection and chronic hepatitis $\mathrm{E}$ in liver transplant recipients in Japan. EBioMedicine 2: 1607-1612.

Ingiliz P, Mayr C, Obermeier M, Herbst H, Polywka S, Pischke S. 2016. Persisting hepatitis E virus infection leading to liver cirrhosis despite recovery of the immune system in an HIV-infected patient. Clin Res Hepatol Gastroenterol 40: e23-e25.

Izopet J, Dubois M, Bertagnoli S, Lhomme S, Marchandeau S, Boucher S, Kamar N, Abravanel F, Guerin JL. 2012. Hepatitis $\mathrm{E}$ virus strains in rabbits and evidence of a closely related strain in humans, France. Emerg Infect Dis 18: 1274-1281.

Kamar N, Selves J, Mansuy JM, Ouezzani L, Peron JM, Guitard J, Cointault O, Esposito L, Abravanel F, Danjoux M, et al. 2008. Hepatitis E virus and chronic hepatitis in organ-transplant recipients. N Engl J Med 358: 811-817.

Kamar N, Abravanel F, Garrouste C, Cardeau-Desangles I Mansuy JM, Weclawiak H, Izopet J, Rostaing L. 2010a. Three-month pegylated interferon- $\alpha-2 a$ therapy for chronic hepatitis $\mathrm{E}$ virus infection in a haemodialysis patient. Nephrol Dial Transplant 25: 2792-2795.

Kamar N, Abravanel F, Selves J, Garrouste C, Esposito L, Lavayssiere L, Cointault O, Ribes D, Cardeau I, Nogier $\mathrm{MB}$, et al. 2010b. Influence of immunosuppressive therapy on the natural history of genotype 3 hepatitis-E virus infection after organ transplantation. Transplantation 89: 353-360.

Kamar N, Rostaing L, Abravanel F, Garrouste C, Lhomme S, Esposito L, Basse G, Cointault O, Ribes D, Nogier MB, et al. 2010c. Ribavirin therapy inhibits viral replication on patients with chronic hepatitis E virus infection. Gastroenterology 139: 1612-1618.

Kamar N, Bendall RP, Peron JM, Cintas P, Prudhomme L, Mansuy JM, Rostaing L, Keane F, Ijaz S, Izopet J, et al. 2011a. Hepatitis E virus and neurologic disorders. Emerg Infect Dis 17: 173-179.

Kamar N, Garrouste C, Haagsma EB, Garrigue V, Pischke S, Chauvet C, Dumortier J, Cannesson A, Cassuto-Viguier E, Thervet E, et al. 2011b. Factors associated with chronic hepatitis in patients with hepatitis $\mathrm{E}$ virus infection who have received solid organ transplants. Gastroenterology 140: 1481-1489.

Kamar N, Bendall R, Legrand-Abravanel F, Xia NS, Ijaz S, Izopet J, Dalton HR. 2012a. Hepatitis E. Lancet 379: 2477-2488.

Kamar N, Weclawiak H, Guilbeau-Frugier C, LegrandAbravanel F, Cointault O, Ribes D, Esposito L, Cardeau-Desangles I, Guitard J, Sallusto F, et al. 2012b. Hepatitis $\mathrm{E}$ virus and the kidney in solid-organ transplant patients. Transplantation 93: 617-623.

Kamar N, Rostaing L, Legrand-Abravanel F, Izopet J. 2013. How should hepatitis E virus infection be defined in organ-transplant recipients? Am J Transplant 13: 19351936.

Kamar N, Izopet J, Tripon S, Bismuth M, Hillaire S, Dumortier J, Radenne S, Coilly A, Garrigue V, D'Alteroche L, et al. 2014. Ribavirin for chronic hepatitis $\mathrm{E}$ virus infection in transplant recipients. N Engl J Med 370: 1111-1120. 
Kamar N, Lhomme S, Abravanel F, Cointault O, Esposito L, Cardeau-Desangles I, Del Bello A, Dorr G, Lavayssiere L, Nogier MB, et al. 2015. An early viral response predicts the virological response to ribavirin in hepatitis E virus organ transplant patients. Transplantation 99: 21242131.

Kamar N, Marion O, Abravanel F, Izopet J, Dalton HR. 2016. Extrahepatic manifestations of hepatitis E virus. Liver Int 36: $467-472$

Kamar N, Wang W, Dalton HR, Pan Q. 2017. Direct-acting antiviral therapy for hepatitis E virus? Lancet Gastroenterol Hepatol 2: 154-155.

Kaushik N, Subramani C, Anang S, Muthumohan R, Shalimar, Nayak B, Ranjith-Kumar CT, Surjit M. 2017. Zinc salts block hepatitis $\mathrm{E}$ virus replication by inhibiting the activity of viral RNA-dependent RNA polymerase. J Virol 91: e00754.

Kolachi NF, Kazi TG, Afridi HI, Kazi N, Kandhro GA, Shah AQ, Baig JA, Wadhwa SK, Khan S, Shah F, et al. 2011. Distribution of copper, iron, and zinc in biological samples (scalp hair, serum, blood, and urine) of Pakistani viral hepatitis (A-E) patients and controls. Biol Trace Elem Res 143: 116-130.

Kumar A, Saraswat VA. 2013. Hepatitis E and acute-onchronic liver failure. J Clin Exp Hepatol 3: 225-230.

Lachish T, Erez O, Daudi N, Shouval D, Schwartz E. 2015. Acute hepatitis $\mathrm{E}$ virus in pregnant women in Israel and in other industrialized countries. J Clin Virol 73: 20-24.

* Lanford RE, Walker CM, Lemon SM. 2018. Nonhuman primate models of hepatitis A virus and hepatitis E virus infections. Cold Spring Harb Perspect Med doi: 10.1101/ cshperspect.a031815.

Lee GH, Tan BH, Chi-Yuan Teo E, Lim SG, Dan YY, Wee A, Aw PP, Zhu Y, Hibberd ML, Tan CK, et al. 2016. Chronic infection with camelid hepatitis $\mathrm{E}$ virus in a liver transplant recipient who regularly consumes camel meat and milk. Gastroenterology 150: 355-357.e353.

Legrand-Abravanel F, Kamar N, Sandres-Saune K, Garrouste C, Dubois M, Mansuy JM, Muscari F, Sallusto F, Rostaing L, Izopet J. 2010. Characteristics of autochthonous hepatitis $\mathrm{E}$ virus infection in solid-organ transplant recipients in France. J Infect Dis 202: 835-844.

Legrand-Abravanel F, Kamar N, Sandres-Saune K, Lhomme S, Mansuy JM, Muscari F, Sallusto F, Rostaing L, Izopet J. 2011. Hepatitis $\mathrm{E}$ virus infection without reactivation in solid-organ transplant recipients, France. Emerg Infect Dis 17: 30-37.

Lhomme S, Abravanel F, Dubois M, Sandres-Saune K, Rostaing L, Kamar N, Izopet J. 2012. Hepatitis E virus quasispecies and the outcome of acute hepatitis $\mathrm{E}$ in solidorgan transplant patients. J Virol 86: 10006-10014.

Lhomme S, Abravanel F, Dubois M, Sandres-Saune K, Mansuy JM, Rostaing L, Kamar N, Izopet J. 2014. Characterization of the polyproline region of the hepatitis $\mathrm{E}$ virus in immunocompromised patients. J Virol 88: 12017-12025.

Lhomme S, Kamar N, Nicot F, Ducos J, Bismuth M, Garrigue V, Petitjean-Lecherbonnier J, Ollivier I, Alessandri-Gradt E, Goria O, et al. 2015. Mutation in the hepatitis E virus polymerase and outcome of ribavirin therapy. Antimicrob Agents Chemother 60: 1608-1614.

Mallet V, Nicand E, Sultanik P, Chakvetadze C, Tesse S, Thervet E, Mouthon L, Sogni P, Pol S. 2010. Brief com- munication: Case reports of ribavirin treatment for chronic hepatitis E. Ann Intern Med 153: 85-89.

Meldal BH, Sarkodie F, Owusu-Ofori S, Allain JP. 2013. Hepatitis E virus infection in Ghanaian blood donorsThe importance of immunoassay selection and confirmation. Vox Sang 104: 30-36.

Neukam K, Barreiro P, Macias J, Avellon A, Cifuentes C, Martin-Carbonero L, Echevarria JM, Vargas J, Soriano V, Pineda JA. 2013. Chronic hepatitis E in HIV patients: Rapid progression to cirrhosis and response to oral ribavirin. Clin Infect Dis 57: 465-468.

Peron JM, Bureau C, Poirson H, Mansuy JM, Alric L, Selves J, Dupuis E, Izopet J, Vinel JP. 2007. Fulminant liver failure from acute autochthonous hepatitis $\mathrm{E}$ in France: Description of seven patients with acute hepatitis $\mathrm{E}$ and encephalopathy. J Viral Hepat 14: 298-303.

Peron JM, Dalton H, Izopet J, Kamar N. 2011. Acute autochthonous hepatitis $\mathrm{E}$ in western patients with underlying chronic liver disease: A role for ribavirin? J Hepatol 54: 1323-1324; author reply 1324-1325.

Pischke S, Wedemeyer H. 2015. Hepatitis E in transplant recipients: Why is this not a problem in Japan? EBioMedicine 2: 1564-1565.

Pischke S, Suneetha PV, Baechlein C, Barg-Hock H, Heim A, Kamar N, Schlue J, Strassburg CP, Lehner F, Raupach R, et al. 2010. Hepatitis E virus infection as a cause of graft hepatitis in liver transplant recipients. Liver Transpl 16: 74-82.

Pischke S, Stiefel P, Franz B, Bremer B, Suneetha PV, Heim A, Ganzenmueller T, Schlue J, Horn-Wichmann R, Raupach $\mathrm{R}$, et al. 2012. Chronic hepatitis $\mathrm{E}$ in heart transplant recipients. Am J Transplant 12: 3128-3133.

Pischke S, Hardtke S, Bode U, Birkner S, Chatzikyrkou C, Kauffmann W, Bara CL, Gottlieb J, Wenzel J, Manns MP, et al. 2013. Ribavirin treatment of acute and chronic hepatitis E: A single-centre experience. Liver Int 33: 722-726.

Pischke S, Hiller J, Lutgehetmann M, Polywka S, Rybczynski M, Ayuk F, Lohse AW. 2016. Blood-borne hepatitis E virus transmission: A relevant risk for immunosuppressed patients. Clin Infect Dis 63: 569-570.

Pischke S, Hartl J, Pas SD, Lohse AW, Jacobs BC, Van der Eijk AA. 2017. Hepatitis E virus: Infection beyond the liver? J Hepatol 66: 1082-1095.

Rein DB, Stevens GA, Theaker J, Wittenborn JS, Wiersma ST. 2012. The global burden of hepatitis E virus genotypes 1 and 2 in 2005. Hepatology 55: 988-997.

Riezebos-Brilman A, Puchhammer-Stockl E, van der Weide HY, Haagsma EB, Jaksch P, Bejvl I, Niesters HG, Verschuuren EA. 2013. Chronic hepatitis E infection in lung transplant recipients. J Heart Lung Transplant 32: 341-346.

Roth NJ, Schafer W, Alexander R, Elliott K, Elliott-Browne W, Knowles J, Wenzel JJ, Simon TL. 2017. Low hepatitis E virus RNA prevalence in a large-scale survey of United States source plasma donors. Transfusion 57: 2958-2964.

Sauleda S, Ong E, Bes M, Janssen A, Cory R, Babizki M, Shin T, Lindquist A, Hoang A, Vang L, et al. 2014. Seroprevalence of hepatitis E virus (HEV) and detection of HEV RNA with a transcription-mediated amplification assay in blood donors from Catalonia (Spain). Transfusion 55: 972-979. 
N. Kamar and S. Pischke

Shimakawa Y, Njai HF, Takahashi K, Berg L, Ndow G, JengBarry A, Ceesay A, Tamba S, Opoku E, Taal M, et al. 2016. Hepatitis E virus infection and acute-on-chronic liver failure in West Africa: A case-control study from The Gambia. Aliment Pharmacol Ther 43: 375-384.

Stevens O, Claeys KG, Poesen K, Saegeman V, Van Damme P. 2017. Diagnostic challenges and clinical characteristics of hepatitis E virus-associated Guillain-Barré syndrome. JAMA Neurol 74: 26-33.

Stramer SL. 2014. Current perspectives in transfusion-transmitted infectious diseases: Emerging and re-emerging infections. ISBT Sci Ser 9: 30-36.

Suneetha PV, Pischke S, Schlaphoff V, Grabowski J, Fytili P, Gronert A, Bremer B, Markova A, Jaroszewicz J, Bara C, et al. 2012. Hepatitis E virus (HEV)-specific T-cell responses are associated with control of HEV infection. Hepatology 55: 695-708.

Tamura A, Shimizu YK, Tanaka T, Kuroda K, Arakawa Y, Takahashi K, Mishiro S, Shimizu K, Moriyama M. 2007. Persistent infection of hepatitis $\mathrm{E}$ virus transmitted by blood transfusion in a patient with T-cell lymphoma. Hepatol Res 37: 113-120.

Taton B, Moreau K, Lepreux S, Bachelet T, Trimoulet P, De Ledinghen V, Pommereau A, Ronco P, Kamar N, Merville $\mathrm{P}$, et al. 2013. Hepatitis E virus infection as a new probable cause of de novo membranous nephropathy after kidney transplantation. Transpl Infect Dis 15: E211-E215.

Tavitian S, Peron JM, Huguet F, Kamar N, Abravanel F, Beyne-Rauzy O, Oberic L, Faguer S, Alric L, Roussel M, et al. 2015. Ribavirin for chronic hepatitis prevention among patients with hematologic malignancies. Emerg Infect Dis 21: 1466-1469.

Todt D, Gisa A, Radonic A, Nitsche A, Behrendt P, Suneetha PV, Pischke S, Bremer B, Brown RJ, Manns MP, et al 2016. In vivo evidence for ribavirin-induced mutagenesis of the hepatitis E virus genome. Gut 65: 1733-1743.

van den Berg B, van der Eijk AA, Pas SD, Hunter JG, Madden RG, Tio-Gillen AP, Dalton HR, Jacobs BC. 2014 Guillain-Barré syndrome associated with preceding hepatitis E virus infection. Neurology 82: 491-497.

van der Valk M, Zaaijer HL, Kater AP, Schinkel J. 2017. Sofosbuvir shows antiviral activity in a patient with chronic hepatitis E virus infection. J Hepatol 66: 242-243.

van Eijk JJ, Madden RG, van der Eijk AA, Hunter JG, Reimerink JH, Bendall RP, Pas SD, Ellis V, van Alfen N, Beynon L, et al. 2014. Neuralgic amyotrophy and hepatitis E virus infection. Neurology 82: 498-503.

van Eijk JJJ, Dalton HR, Ripellino P, Madden RG, Jones C, Fritz M, Gobbi C, Melli G, Pasi E, Herrod J, et al. 2017. Clinical phenotype and outcome of hepatitis E virus-associated neuralgic amyotrophy. Neurology 89: 909-917.
Versluis J, Pas SD, Agteresch HJ, de Man RA, Maaskant J, Schipper ME, Osterhaus AD, Cornelissen JJ, van der Eijk AA. 2013. Hepatitis E virus: An underestimated opportunistic pathogen in recipients of allogeneic hematopoietic stem cell transplantation. Blood 122: 1079-1086.

Vollmer T, Diekmann J, Johne R, Eberhardt M, Knabbe C, Dreier J. 2012. Novel approach for detection of hepatitis E virus infection in German blood donors. J Clin Microbiol 50: 2708-2713.

Wang Y, Zhou X, Debing Y, Chen K, Van der Laan LJ, Neyts J, Janssen HL, Metselaar HJ, Peppelenbosch MP, Pan Q. 2014. Calcineurin inhibitors stimulate and mycophenolic acid inhibits replication of hepatitis E virus. Gastroenterology 146: 1775-1783.

Wang L, Xia J, Wang L, Wang Y. 2016a. Experimental infection of rabbits with genotype 3 hepatitis $\mathrm{E}$ virus produced both chronicity and kidney injury. Gut 66: 561-562.

Wang W, Hakim MS, Nair VP, de Ruiter PE, Huang F, Sprengers D, Van Der Laan LJ, Peppelenbosch MP, Surjit M, Pan Q. 2016b. Distinct antiviral potency of sofosbuvir against hepatitis $\mathrm{C}$ and $\mathrm{E}$ viruses. Gastroenterology 151: 1251-1253.

Wedemeyer H, Pischke S. 2011. Hepatitis: Hepatitis E vaccination-Is HEV 239 the breakthrough? Nat Rev Gastroenterol Hepatol 8: 8-10.

Wedemeyer H, Pischke S, Manns MP. 2012. Pathogenesis and treatment of hepatitis E virus infection. Gastroenterology 142: 1388-1397.e1381.

Williams TP, Kasorndorkbua C, Halbur PG, Haqshenas G, Guenette DK, Toth TE, Meng XJ. 2001. Evidence of extrahepatic sites of replication of the hepatitis $\mathrm{E}$ virus in a swine model. J Clin Microbiol 39: 3040-3046.

Xu A, Tao Z, Lin X, Liu Y, Zhang Y, Song L, Wang H, Yang J, Li Y, Ji F, et al. 2011. The complete genome sequence of an enterovirus 76 isolate in China reveals a recombination event. Arch Virol 156: 1685-1689.

Xu C, Wang RY, Schechterly CA, Ge S, Shih JW, Xia NS, Luban NL, Alter HJ. 2013. An assessment of hepatitis E virus (HEV) in US blood donors and recipients: No detectable HEV RNA in 1939 donors tested and no evidence for HEV transmission to 362 prospectively followed recipients. Transfusion 53: 2505-2511.

Zhang S, Chen C, Peng J, Li X, Zhang D, Yan J, Zhang Y, Lu C, Xun J, Li W, et al. 2017. Investigation of underlying comorbidities as risk factors for symptomatic human hepatitis E virus infection. Aliment Pharmacol Ther 45: 701-713.

Zhu FC, Zhang J, Zhang XF, Zhou C, Wang ZZ, Huang SJ, Wang H, Yang CL, Jiang HM, Cai JP, et al. 2010. Efficacy and safety of a recombinant hepatitis $\mathrm{E}$ vaccine in healthy adults: A large-scale, randomised, double-blind placebocontrolled, phase 3 trial. Lancet 376: 895-902. 


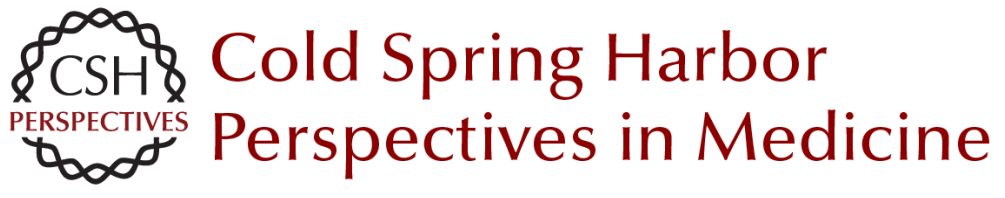

\title{
Acute and Persistent Hepatitis E Virus Genotype 3 and 4 Infection: Clinical Features, Pathogenesis, and Treatment
}

\author{
Nassim Kamar and Sven Pischke \\ Cold Spring Harb Perspect Med 2019; doi: 10.1101/cshperspect.a031872 originally published online May \\ 7, 2018
}

\section{Subject Collection Enteric Hepatitis Viruses}

Hepatitis A Virus Genome Organization and

Replication Strategy

Kevin L. McKnight and Stanley M. Lemon

Adaptive Immune Responses in Hepatitis A Virus and Hepatitis E Virus Infections Christopher M. Walker

Small Animal Models of Hepatitis E Virus Infection Tian-Cheng Li and Takaji Wakita

Acute and Persistent Hepatitis E Virus Genotype 3 and 4 Infection: Clinical Features, Pathogenesis, and Treatment

Nassim Kamar and Sven Pischke

Epidemiology of Genotype 1 and 2 Hepatitis E

Virus Infections

Kenrad E. Nelson, Alain B. Labrique and Brittany L. Kmush

History of the Discovery of Hepatitis A Virus Stephen M. Feinstone

Epidemiology and Transmission of Hepatitis A Virus and Hepatitis E Virus Infections in the United States

Megan G. Hofmeister, Monique A. Foster and Eyasu H. Teshale

Stem Cell-Derived Culture Models of Hepatitis E Virus Infection Viet Loan Dao Thi, Xianfang Wu and Charles M. Rice
Evolutionary Origins of Enteric Hepatitis Viruses Anna-Lena Sander, Victor Max Corman, Alexander N. Lukashev, et al.

Enterically Transmitted Non-A, Non-B Hepatitis and the Discovery of Hepatitis E Virus Stanley M. Lemon and Christopher M. Walker

Natural History, Clinical Manifestations, and

Pathogenesis of Hepatitis E Virus Genotype 1 and 2 Infections

Rakesh Aggarwal and Amit Goel

Hepatitis A Virus and Hepatitis E Virus: Emerging and Re-Emerging Enterically Transmitted

Hepatitis Viruses

Stanley M. Lemon and Christopher M. Walker

Hepatitis A Virus Capsid Structure

David I. Stuart, Jingshan Ren, Xiangxi Wang, et al.

Comparative Pathology of Hepatitis A Virus and

Hepatitis E Virus Infection John M. Cullen and Stanley M. Lemon

Innate Immunity to Enteric Hepatitis Viruses Zongdi Feng and Stanley M. Lemon

Nonhuman Primate Models of Hepatitis A Virus and Hepatitis E Virus Infections

Robert E. Lanford, Christopher M. Walker and Stanley M. Lemon

For additional articles in this collection, see http://perspectivesinmedicine.cshlp.org/cgi/collection/ 